\title{
Correction to: Content validation of the EORTC QLQ-C15-PAL with advanced cancer patients and health care professionals from palliative care services in Chile
}

Leslye Rojas-Concha ${ }^{1,2^{*}}$, Maiken Bang Hansen ${ }^{1}$, Morten Aagaard Petersen ${ }^{1}$ and Mogens Groenvold ${ }^{1,2}$

\section{Correction to: BMC Palliat Care 19, 81 (2020) \\ https://doi.org/10.1186/s12904-020-00586-1}

Following publication of the original article [1], the authors identified an error in Table 3. The footnotes were missing. Provided below is the correct Table with its footer.

Published online: 12 October 2020

\section{Reference}

1. Rojas-Concha L, Hansen MB, Petersen MA, Groenvold M. Content validation of the EORTC QLQ-C15-PAL with advanced cancer patients and health care professionals from palliative care services in Chile. BMC Palliat Care. 2020;19: 81 https://doi.org/10.1186/s12904-020-00586-1.

The original article can be found online at https://doi.org/10.1186/s12904020-00586-1.

* Correspondence: leslye.alejandra.rojas.concha@regionh.dk

${ }^{1}$ The Palliative Care Research Unit, Department of Geriatrics and Palliative Medicine GP, Bispebjerg and Frederiksberg Hospital, University of

Copenhagen, Bispebjerg Bakke 23, DK-2400 Copenhagen, NV, Denmark ${ }^{2}$ Department of Public Health, University of Copenhagen, Copenhagen, Denmark

(c) The Author(s). 2020 Open Access This article is licensed under a Creative Commons Attribution 4.0 International License, which permits use, sharing, adaptation, distribution and reproduction in any medium or format, as long as you give appropriate credit to the original author(s) and the source, provide a link to the Creative Commons licence, and indicate if changes were made. The images or other third party material in this article are included in the article's Creative Commons licence, unless indicated otherwise in a credit line to the material. If material is not included in the article's Creative Commons licence and your intended use is not permitted by statutory regulation or exceeds the permitted use, you will need to obtain permission directly from the copyright holder. To view a copy of this licence, visit http://creativecommons.org/licenses/by/4.0/ The Creative Commons Public Domain Dedication waiver (http://creativecommons.org/publicdomain/zero/1.0/) applies to the data made available in this article, unless otherwise stated in a credit line to the data. 
Table 3 Categorized reasons why some items were rated as little or not relevant by the participants

\begin{tabular}{|c|c|c|c|c|c|c|c|c|c|c|c|c|c|c|}
\hline \multirow[t]{2}{*}{ Scale/item } & \multirow[t]{2}{*}{ Item } & \multicolumn{2}{|c|}{ Relevance $^{a}$} & \multicolumn{2}{|c|}{ Technical issues $^{\mathbf{b}}$} & \multicolumn{2}{|c|}{ Inappropriate $^{c}$} & \multicolumn{2}{|c|}{ Relative $^{d}$} & \multicolumn{2}{|c|}{ Not important ${ }^{\mathrm{e}}$} & \multicolumn{2}{|c|}{ Difficult $^{f}$} & \multirow[t]{2}{*}{ Tota } \\
\hline & & Pts. & HCPs & Pts. & HCPs & Pts. & HCPs & Pts. & HCPs & Pts. & HCPs & Pts. & HCPs & \\
\hline \multirow[t]{2}{*}{ Pain } & 9 & & & & 1 & & & & & & & & & 1 \\
\hline & 19 & & 3 & & 1 & & 2 & 1 & & & & & & 7 \\
\hline \multirow[t]{5}{*}{ Physical functioning } & 1 & 5 & 5 & & & 3 & 3 & 1 & & & & & & 17 \\
\hline & 2 & 4 & 6 & 1 & 1 & 1 & & 1 & & 1 & 1 & & & 16 \\
\hline & 3 & 4 & 6 & 1 & 2 & 1 & 1 & 1 & & 1 & & & & 17 \\
\hline & 4 & 3 & & & & 2 & 1 & 1 & & & & & 1 & 8 \\
\hline & 5 & & & & & & & & & & & & & - \\
\hline \multirow[t]{4}{*}{ Emotional functioning } & 21 & 1 & 5 & 1 & 2 & & 1 & & 1 & & 1 & 1 & & 13 \\
\hline & 22 & 1 & 5 & 2 & 1 & & & 1 & & 1 & 1 & & & 12 \\
\hline & 23 & & 1 & 4 & 5 & & & 1 & & & 1 & & & 12 \\
\hline & 24 & & 2 & & 3 & & & 1 & & & & & & 6 \\
\hline \multirow[t]{3}{*}{ Fatigue } & 10 & & 5 & & 1 & & 1 & 1 & & 1 & 1 & & & 10 \\
\hline & 12 & & 3 & 2 & 3 & & 1 & 2 & & & & & 1 & 12 \\
\hline & 18 & 1 & 4 & 1 & & & 1 & 2 & & & 1 & & & 10 \\
\hline \multirow[t]{2}{*}{ Nausea and vomiting } & 14 & 1 & 2 & & 2 & & & & & & & & & 5 \\
\hline & 15 & & 2 & & 1 & & & & & & & & & 3 \\
\hline Sleeping difficulties & 11 & & & & 1 & & & & & & & & & 1 \\
\hline \multirow[t]{2}{*}{ Social functioning } & 26 & 1 & & & & 1 & 1 & 1 & & & 1 & & & 5 \\
\hline & 27 & & 1 & & 2 & 2 & & 1 & & & 2 & & & 8 \\
\hline Dyspnea & 8 & 3 & 5 & 14 & 13 & 1 & & 1 & & 1 & & 1 & & 39 \\
\hline \multirow[t]{2}{*}{ Role functioning } & 6 & 2 & 1 & & 3 & & & & & & 1 & & & 7 \\
\hline & 7 & 4 & 11 & & 1 & 1 & 2 & 1 & & & & & & 20 \\
\hline Constipation & 16 & & 1 & 10 & 7 & & & & & & & & & 18 \\
\hline Lack of appetite & 13 & & 1 & & & & & & & & & & & 1 \\
\hline Financial difficulties & 28 & 1 & 2 & & 1 & 2 & 1 & & & & & 1 & & 8 \\
\hline Global health status/ & 29 & & 2 & 1 & & & & & & & & & 1 & 4 \\
\hline Quality of life & 30 & & 1 & 2 & 3 & & 1 & 1 & & & & 1 & 1 & 10 \\
\hline \multirow[t]{2}{*}{ Cognitive functioning } & 20 & 4 & 11 & & 1 & & 1 & & & & 4 & & & 21 \\
\hline & 25 & 1 & 8 & & 1 & & & & 1 & & & & & 11 \\
\hline Diarrhea & 17 & & 3 & & & 1 & & & 1 & & & & & 5 \\
\hline Total & & 36 & 96 & 39 & 56 & 15 & 17 & 18 & 3 & 5 & 14 & 4 & 4 & 307 \\
\hline
\end{tabular}

a Relevance: statements concerning the degree of relevance, i.e., replicating the quantitative data

${ }^{\mathrm{b}}$ Technical issues: statements that the question is not well formulated, reiterative or suggestions to combine items

c Inappropriate: statements that the item was inappropriate

${ }^{\mathrm{d}}$ Relative: statements that the symptom or problem asked in the item depend of patient's diagnosis

e Not important: statements that the item was not important in palliative care

${ }^{f}$ Difficult: the item was seen has difficult to understand

Patients: Pts., health care professionals: HCPs 